\title{
THE MEDICINAL USES OF TINOSPORA CORDIFOLIA (GURJO)
}

\author{
Suraj Raj Adhikari ${ }^{1 *}$ and Kusum Pokhrel ${ }^{2}$ \\ ${ }^{1}$ Department of Botany, Prithvi Narayan Campus, Tribhuvan University, Pokhara, Nepal \\ ${ }^{2}$ Gogan Secondary School, Pokhara-32, Nepal \\ *For correspondence: adhikarisr@gmail.com
}

\begin{abstract}
Tinospora cordifolia is a perennial, climbing deciduous shrub. This plant belongs to the family Menispermaceae. A variety of phytochemical constituents have been isolated from different parts of T. cordifolia. These compounds belong to different groups such as alkaloids, steroids, diterpenoid lactones, aliphatic compounds, glycosides and polysaccharides. It is a widely used plant in Ayurvedic systems of medicine. Stem, roots and leaves are the most important parts of the plant, which are used in traditional systems of medicines. It possesses anti-neoplastic, antioxidant, anti-hyperglycemic and hepatoprotective properties. It is the important medicinal plant used in traditional Ayurvedic medicine for the treatment of fever, cold, diabetes, respiratory tract infections etc. This paper presents an appraisal of medicinal properties and pharmaceutical importance of Tinospora cordifolia.
\end{abstract}

Keywords - antioxidant activity, herbal drugs, phytoconstituents, Tinospora cordifolia.

\section{INTRODUCTION}

The World Health Organization (WHO) estimated that up to $80 \%$ of people still rely mainly on traditional remedies such as medicinal plants for their medicines. Since the beginning of human civilization, plants have been used as natural medicines (Bharathi, 2018). Recently, scientists are showing a great interest in the isolation of new drugs from traditional medicinal plants. Tinospora cordifolia is also commonly named as "Gurjo" (Nepali) and or "Gulancha" in English. It is distributed in the tropical and sub-tropical regions in Nepal. It is also found in various countries of Asia such as China, Thailand, Sri Lanka, Malaysia , Philippines, and Africa (Raghu et al., 2006). It has been given various names i.e. gurjo, heart-leaved moonseed, guduchi, giloy etc. It is a popular medicinal plant in Atharva Veda and ancient Ayurvedic literature. This paper emphasizes on the information related to the morphology of Gurjo plant and their medicinal value.

Nepal is rich in biodiversity and huge knowledge of ancient traditional systems of medicine such as Ayurveda, Amchi etc. provide a strong base for the utilization of a large number of plants in healthcare. Demand for Ayurvedic plants is high in both developing and developed countries.

Tinospora cordifolia (willd) is a deciduous climbing shrub which belongs to the family Menispermaceae. It grows in a wide range of soil, acidic to alkaline with moderate level of soil moisture. The plant has diverse medicinal property and help to boost the immune system and body's defense against Micro-organisms and virus (Tirtha, 2007). This plant is rich source of phenolics, alkaloids, sesquiterpenoid, polysaccharides, glycosides and steroids. So, researchers show huge interest in this plant with high curiosity due to its immense pharmaceutical value like anti-ageing, immunomodulatory, 
anti-diabetic, anti-arthritic, anti-inflammatory etc. (Goel et al., 2014; Panchabhai et al., 2008).

\section{Morphological description}

Tinospora cordifolia is a large, glabrous, perennial, deciduous, climbing shrub. The stem is fleshy, succulent and climbing in nature with long filiform fleshy aerial roots. The bark is creamy white to grey, and stem contains rosette like lenticles. Its leaves are simple, heart shaped, ovate, alternate or lobed, about 7-9 nerved and membranous (Albinjose et al., 2015; Dwivedi et al., 2016; Meshram et al., 2013). The thread like, aerial and long filiform roots are usually arising from the branches (Singh et al., 2003). Its flowers bloom in summer, flowers are in axillary position, $2-9 \mathrm{~cm}$ long raceme on leaflet branches, unisexual, small and yellow in colour. Male flowers are clustered while female are usually solitary. There are six sepals that are arranged in two whorls and are yellowish green in colour (Joshi et al., 2016). Fruits are developing during winter season. Fruit of this plant are fleshy, orange reddish when fully matured. The seeds are curved (Shetty et al., 2010).

\section{CHEMICAL COMPOSITION}

A variety of constituents have been isolated from different parts of Tinospora cordifolia. They belong to different classes such as alkaloids, Steroids, Glycosides, Diterpenoid lactones, Sesquiterpenoid, Sesquiterpenoid etc (Nasreem et al. 2010). Few important alkaloids found in the stem and root of Tinospora cordifolia are Berberine, Palmatine, Magnoflorine, Tembetarine, Choline, Palmatine, Tinosporin, Isocolumbin, Tetrahydropalmatine, Magnoflorine (Singh et al., 2003; Sinha et al., 2004). Steroids found in the stem of T. cordifolia are Ecdysterone, Giloinsterol , Makisterone A, b-sitosterol, d-sitosterol, ecdysterone, g- sitosterol, b-hydroxygenase, makisterone, giloinsteroljateorine, columbin (Singh et al., 2003). Glycosides found in the stem are 18-norclerodane glucoside, Furanoidditerpeneglucoside, Tinocordiside, Tinocordifolioside, Cordioside, Cordifolioside, Cordifolioside Syringin, Syringinapiosylglycoside, Palmatosides, Palmatosides, Cordifoliside A, Cordiofoliside B, Cordifoliside C, Cordifoliside D, Cordifoliside E (Singh et al., 2003; Gagan et al., 1994; Wazir et al., 1995; Gagan et al., 1996; Maurya et al., 1997; Ghosal et al., 1997). Diterpenoid lactones are Furanolactone, Clerodane derivatives, Tinosporon, Tinosporides, Jateorine, Columbin (Singh et al., 2003; Maurya et al., 1997; Maurya et al., 1989; Swami Nathan et al., 1989). Aliphatic compound are Octacosanol, heptacosanol, nonacosan15-one (Singh et al., 2003; Thippeswamy et al., 2008) and Miscellaneous compounds are Tinosporidine, cordifol, cordifelone, N-transferuloyl tyramine as diacetate, giloin, gilonin, tinosporic acid, Jatrorrhizine (Singh et al., 2003; Hanuman et al., 1986).

\section{Medicinal applications}

Tinospora cordifolia is widely used in traditional medicine because of its biological activities like anti-periodic, anti- inflammatory, immunomodulatory, anti-neoplastic activities, anti-oxidant, anti-diabetic, anti-spasmodic, antistress, anti-leprotic, anti-malarial, anti-allergic, anti-arthritic activity, hepato-protective etc. Tinospora cordifolia is used in various ailments fevers, diabetes, asthma, dyspepsia, jaundice, skin diseases, urinary problems, and chronic diarrhoea and dysentery. It is also used in the treatment of leprosy, helminthiasis, heart diseases and rheumatoid arthritis.

The stem of this plant is used in respiratory tract infections, skin diseases (Aiyer et al., 1963; Raghunathan et al., 1982), antidote to snake bite and scorpion sting (Nadkarni et al., 1976), stomachic, diuretic, stimulates bile secretions, allays thirst, enriches the blood and cures 
jaundice (Nayampalli et al., 1988), The juice of plant stem is useful in diabetes, dyspepsia, vaginal and urethral discharges (Singla et al., 2010), radio -protective activity (Chintalwar et al., 1999), jaundice (Sangeetha et.al., 2013) , regulates the blood sugar level (Patel et al., 2011). Bark of stem is used in Anti-inflammatory activity, Anti-allergic, Anti-spasmodic, Antipyretic, Anti-leprotic (Nayampalli et al., 1986; Ikram et al., 1987; Asthana et al., 2001). Root of this plant is used in Anti-neoplastic property, Anti-oxidant activity (Sarma et al., 1998). Whole plant is used in analgesic and neuro pharmacological activities, antidote to snake bite and scorpion sting, antipyretic and antiinflammatory activity (Jeyachandran et al., 2003 ; Gupta et al., 1956), Diabetis, Rheumatoid arthritis, Gout, Cancer, high cholesterol content (Upadhyay et al., 2010), Anti-asthmatic and chronic cough treatment (Spelman et al., 2001), Anaemia, jaundice,normalization of altered liver functions (Karkal et al., 2007), Cardiac disorders (Rao et al., 2005), Anti-leprotic (Asthana et al., 2001). The powder of root and stem is used along with milk for treatment of cancer (Bhatt et al., 1987). The whole plant is used in scabies in swine, diarrhoea, uinary diseases, syphilis, skin diseases, bronchitis, to promote longevity, increase body's resistance and stimulate the immune system (Kapur et al., 2008; Nagarkatti et al., 1994; Rege et al., 1993; Vasudevan et al., 1995). Tinospora cardifolia decreases the tissue damage caused by radiation (Pandey et al., 2015). The plant is also used in treatment of eye disorders and fractures (Devprakash et al., 2011)

\section{CONCLUSIONS}

Tinospora cordifolia with its multiple values, can be the Nobel source of different types of bio chemical compounds. It is highly popular for various types of phytochemical compounds and its biological activity with medicinal application. This review confirms that Tinospora cordifolia has pharmaceutically high valuable nature i.e. antidiabetic, immunomodulatory, anticancer, antimicrobial, antioxidant, antitoxic etc. The presence of such bioactive compounds shows that this plant can be a valuable resource for the preparation of novel medicines used in the treatment of different diseases and disorders in the future.

\section{REFERENCES}

Aiyer, K.N. and M. Kolammal (1963) Pharmacognosy of Ayuevedic Drugs, Series 1. 1st ed. Trivendram: The centeral Research institute.

Albinjose, J., E. Jasmine, T. Selvankumar and K.P. Srinivasakumar (2015) Bioactive compounds of Tinospora cordifolia by gas chromatographymass spectrometry (GCMS). Int. J. of Multi. disci. Resear. and Develop, 2(1): 88-97.

Asthana, J.G., S. Jain, A. Mishra and M.S. Vijaykant (2001) Evaluation of antileprotic herbal drug combinations and their combination with Dapsone. Indian Drugs. 38:82-86.

Asthana, J.G., S. Jain, A. Mishra and M.S. Vijaykanth (2001) "Evaluation of antileprotic herbal drug combinations and their combination with Dapsone". Indian Drugs-Bombay. 38(2):82-86.

Avnish Upadhyay, K., K. Kumar, A. Kumar, and S. Hari Mishra (2010) "Tinospora cordifolia (Willd.) Hook. f. and Thoms. (Guduchi) validation of the Ayurvedic pharmacology through experimental and clinical studies". International Journal of Ayurveda Research. 1(2):112-121.

Bharathi, C., A. Harinatha Reddy, G. Nageswari, B. Sri Lakshmi, M. Soumya, D.S.Vanisri, and B. Venkatappa (2018) A Review on Medicinal Properties of Tinospora cordifolia. International Journal of Scientific Research and Review. 7(12):585-598.

Bhatt, R.P. and S. D. Sabnis (1987) “Contribution to the ethnobotanyof khedbrahma region of North Gujarat". J. Econ. Taxon. Bot. 9:138-145.

Chintalwar, G. and J. Anjali (1999) “An 
immunologically active arabinogalactan from Tinospora cordifolia". Phytochemistry. 52(6):1089-1093.

Devprakash Srinivasan, K.K., T. Subbaraju, S. Gurav and S Singh (2011) "Tinospora cordifolia: A Review on its Ethnobotany, Phytochemical and Pharmacological Profile". Asian Journal of Biochemical and Pharmaceutical Research. 4(1): 291-302.

Dwivedi, S.K. and A. Enespa (2016) Tinospora cordifolia with reference to biological and microbial properties. International Journal of Current Microbiology and Applied Sciences. 5(6) : 446-465.

Gagan, V.D., P. Pradhan, A.T. Sipahimalan and A. Banerji (1996) Palmatosides CF. Diterpene furan glucosides from from Tinospora cordifolia-Structural elucidation by 2D-NMR spectroscopy. Indian Journal of ChemistryOrganic Medicinal Chemistry. 35:630-634.

Gagan, V.D., P. Pradhan, A. T. Sipahimalani and A. Banerji (1994) Cordifoliosides ABC. Norditerpene furan glycosides from Tinospora cordifolia. Phytochemistry. 37:781-786.

Ghosal, S. and R. A. Vishwakarma (1997) Tinocordiside, A new rearranged cadinane sesquiterpene glycoside from Tinospora cordifolia. Journal of Natural Products. 60:839841.

Goel, B., N. Pathak, D.K. Nim, S.K. Singh, R.K. Dixit and R. Chaurasia (2014) Clinical evaluation of analgesic activity of guduchi (Tinospora cordifolia) using animal model. Journal of clinical and diagnostic research JCDR. 8(8).

Gupta, K.C. and R. Viswanathan (1956) Antituberculous substances from plants. Antibiot Chemother. 6:194-195.

Hanuman, J.B., A.K. Mishra and B. Sabata (1986) A natural phenolic lignin from Tinospora cordifolia Miers. Journal of Chemical Society. 1:1181-1186.

Ikram, M., S.G. Khattak and S.N. Gilani (1987) "Antipyretic studies on some indigenous Pakistani medicinal plants II". Journal of
Ethnopharmacology. 19(2):185-192.

Jeyachandran, R., T.F. Xavier and S.P. Anand (2003) Antibacterial activity of stem extracts of Tinospora cordifolia(willd). Ancient science life. 23:40-44.

Joshi, G. and R. Kaur (2016) Tinospora cordifolia: a phytopharmacological review. International journal of Pharmaceutical sciences and research. 7(3): $: 890$.

Kapur, P., H. Jarry, W.Wuttke, B.M.J. Pereira and D.S. Wuttke (2008) "Evaluation of the antiosteoporotic potential of Tinosporacordifolia in female rats". Maturitas. 59(4): 329-338.

Karkal, Y.R. and L.K. Bairy (2007) Safety of aqueouse of Tinospora cordifolia in healthy volunteers: A double blind randomized placebo controlled study. Iranian J Pharmacol Therap. 6:59-61.

Maurya, R., K.L. Dhar and S.S. Handa (1997) A sesquiterpene glucoside from Tinospora cordifolia. Phytochemistry. 44:749-750.

Maurya, R., V. Wazir, A. Tyagi and R.S. Kapil (1995) Clerodane diterpenoids from Tinospora cordifolia. Phytochemistry. 38:659-61.

Meshram, A., S.S. Bhagyawant, S. Gautam and N. Shrivastava(2013) Potential role of Tinospora cordifolia in pharmaceuticals. World J. Pharm. Sci. 2:4615-4625.

Nadkarni, K.M. and A.K. Nadkarni (1976) Indian Materia Medica, Vol 1. 3rd ed. Mumbai: M/S Popular Prakasan Pvt. Ltd.

Nagarkatti, D.S., N.N. Rege, N.K. Desai and S.A. Dahanukar (1994) "Modulation of Kupffer cell activity by Tinospora cordifolia in liver damage". Journal of Postgraduate Medicine. 40(2): 65-67.

Nasreen, S., R. Radha, N. Jayshree, B. Selvaraj and A. Rajendran (2010) "Assessment of quality of Tinospora cordifolia (willd) miers pharmacognostical and phytophysicochemical profile". International Journal of Comprehensive Pharmacy.1(5):1-4.

Nayampalli, S.S., B. D. Ainapure, R.G. Samant, N.K. Kudtarkar. N.K. Desai and K.C. Gupta 
(1988) "A comparative study of diuretic effects of Tinospora cordifolia and hydrochlorothiazide in rats and a preliminary phase I study in human volunteers". Journal of Postgraduate Medicine. 34(4):233-236.

Nayampalli, S.S., N. K. Sunanda and S. S. Desai (1986) "Antiallergic properties of Tinospora cordifolia in animal models". Indian Journal of Pharmacology. 18(4): 250-252.

Panchabhai, T.S., U.P. Kulkarni and N.M. Rege (2008) Validation of therapeutic claims of Tinospora cordifolia: a review. Phytotherapy Research: An International Journal Devoted to Pharmacological and Toxicological Evaluation of Natural Product Derivatives. 22(4):425-441.

Pandey, M., K. Surendra, M.K. Vyas and R. Sharma (2012) "Tinospora cordifolia: A climbing shrub in health care management". International Journal of Pharmaceutical \& Biosciences. 3(4): 612-628.

Patel, M.B. and S. Mishra (2011) "Hypoglycemic activity of alkaloidal fraction of Tinospora cordifolia". Phytomedicine. 18(12), 1045- 1052.

Raghu, A.V., S.P. Geetha, G. Martin,I. Balachandran and P.N. Ravindran (2006) "In vitro clonal propagation through mature nodes of Tinospora cordifolia (Willd.) Hook. F. \&Thoms.: An important ayurvedic medicinal plant". In Vitro Cellular \& Developmental Biolology-Plant. 42 (6):584-588.

Raghunathan, K. and R. Mittra (1982) Pharmacognosy of Indigenous Drugs. New delhi; Centeral Council for Research in Ayurvedic and Siddha.

Rao, P.R., V.K. Kumar, R.K. Viswanath and G.V. Subbaraju (2005) Cardioprotective activity of alcoholic extract of Tinspora cordifolia in ischemia- reperfusion induced myocardial infaraction in rats. Biol Pharm Bull. 28:2319-2322.

Rege, N., R.D. Bapat, R. Koti, N.K. Desai and S. Dahanukar (1993) Immunotherapy with Tinospora cordifolia: A new lead in the management of obstructive jaundice. Indian Journal of Gastroenterology. 12(1): 5-8.
Sangeetha, M.K., CD. Priya and HR Vasanthi (2013) Anti-diabetic property of Tinospora cordifolia and its active compound is mediated through the expression of Glut-4 in L6 myotubes. Phytomedicine. 20(3-4):246-248.

Sarma, D., P. Padma and R.L. Khosa (1998) Constituents of Tinospora cordifolia root. Fitoterapis. 69:541-542.

Shetty, B.V. and V. Singh (2010) Flora of Rajasthan. 1st edition, Merrut publishers and Distributors, Merrut. Vol 1.

Singh, S.S., S.C. Pandey, S. Srivastava, V.S. Gupta, B. Patro, and A.C. Ghosh (2003) Chemistry and medicinal properties of Tinospora cordifolia (Guduchi). Indian journal of pharmacology. 35(2):83-91.

Singla,A., M. A.Priya and P. Singla(2010) Review of Biological Activities of Tinospora cordifolia. Webmed Central Pharmaceutical Sciences. 1(9):113.

Sinha, K., N.P. Mishra, J. Singh and S.P.S. Khanuja (2004) Tinospora cordifolia (Guduchi), a reservoir plant for therapeutic applications: A review. Indian Journal of Traditional Knowledge. 3:257-270.

Spelman, K., (2001) Traditional and clinical uses of Tinospora cordifolia, guduchi. Aust J Med Herbalism. 13:49-57.

Swaminathan, K., U.C. Sinha, R.K. Bhatt and B.K. Sabata (1989) Structure of tinosporide, A diterpenoid furanolactone from Tinospora cordifolia Miers. Acta Crystallogr. 45:134-136.

Thippeswamy, G., M.L. Sheela and B.P. Salimath (2008) Octacosanol isolated from Tinospora cordifolia downregulates VEG F gene expression by inhibiting nuclear translocation of NF- and its DNA binding activity. Eur J Pharmacol. 588:141-150.

Tirtha, S.S. (2007) The Ayurveda EncyclopediaNatural Secrets to Healing, Prevention and Longevity.

Vasudevan, D.M. and S. Sreekumari(1995) Text book of biochemistry for medical students. Jaypee Brothers Medical, New Delhi. 